\title{
Teacher Absenteeism and Retention: The Predictive Relationship between Principal Leadership Style and Perceived Ethic of Care
}

\author{
George O. Cunningham, Ed.D. \\ Hampton City Schools \\ 1 Franklin Street \\ Hampton, VA 23669 \\ USA \\ Linda D. Grooms, Ph.D. \\ Regent University \\ 1000 Regent University Drive \\ Virginia Beach, VA 23464 \\ USA
}

\begin{abstract}
Finding and retaining highly qualified $K-12$ teachers is one of the most important tasks for a school principal. While the classroom teacher has been shown to be the key component in student academic success, the learning environment, particularly in urban schools, is often compromised by high teacher absenteeism and turnover, issues that cause one to question if principal leadership style and their perceived ethic of care make a difference. Utilizing the Caring School Leadership Questionnaire, data were gathered from 293 PreK-12 teachers in two urban school divisions located in the southeastern United States. Although statistical significance was not realized concerning the predictive value of caring school principals employing transformational, authentic, or servant leadership on teacher absenteeism, teacher retention could be predicted.
\end{abstract}

Keywords: ethic of care, transformational leadership, authentic leadership, servant leadership, urban schools, teacher absenteeism, and teacher retention

\section{Introduction}

Research (Lynch, 2012; Sammons, Gu, Day, \& Ko, 2011) has revealed that school principals have the most significant impact on hiring and retaining highly qualified teachers, however, they must also mitigate many daunting challenges found in urban areas including higher numbers of children living in poverty, homelessness, lower parental engagement, greater issues of student disciplinary issues, a lack of fiscal and material resources, teacher absenteeism, and even teacher turnover. While exploring the leading indicators of increased teacher absenteeism in one urban school division, Miller, Murnane, and Willett (2008) found that frequent stressful work experiences resulted in teachers taking many more discretionary days. Similarly, Clotfelter, Ladd, and Vigdor (2009) found that teachers who entered the profession working in urban environments, tended to be chronically absent during their initial four years of employment. However, principal leadership styles such as transformational, authentic, and servant leadership share a commonality in lowering teacher absenteeism due to an emphasis in building principal-teacher relationships (Avolio \& Gardner, 2005; Bass \& Riggio, 2006; Frooman, Mendelson, \& Murphy, 2012; Greenleaf, 1977; Shapira-Lishchinsky \& Tsemach, 2014). At the core of these relationships, principals who employ the ethic of care foster an environment conducive to not only lowering absenteeism but also increasing retention.

\section{Background/Literature Review}

Since the classroom teacher has the highest impact on student achievement, it is disconcerting that Miller et al. (2008) highlighted that over the course of 13 years of K-12 education, students could spend up to one academic year with a substitute teacher. Similarly, the National Council on Teacher Quality (2014) reported that U.S. teachers in the largest urban areas for the 2012-2013 school year were absent for nearly 11 days out of an average school year of 186, and $16 \%$ of all teachers were listed in the chronically absent category as a result of missing 18 days or more. In addition, while teachers new to the profession altogether are exiting within the first five years of employment, this turnover is more severe in urban and high-poverty areas (Ingersoll, Merrill, \& Stuckey, 2014). 
In their study on identifying warning indicators to teacher attrition, Gallant and Riley (2014) found that a lack of emotional support from school leadership was a common theme. So, one must question, does the ethic of care as implemented by school principals increase teacher retention in the classroom?

\subsection{The Ethic of Care}

Carol Gilligan (1982), a former student of Lawrence Kohlberg (1968) who developed the Stages of Moral Development, argued that his research assumed that the maintaining of relationships was subordinate to law and order. Subsequently, she founded the ethic of care, which presupposed developing creative solutions and promoting compromise when problem solving to ensure equity was just as important, if not more so, than the ethic of justice associated with Kohlberg's research. Therefore, this care-based perspective concentrates on the interconnectedness of relationships among individuals, behaving in a just manner, and helping others in need (Atwijuka \& Caldwell, 2017; Gilligan, 1982; Machold, Ahmed, \& Farquhar, 2008; Noddings, 1984).

Gilligan (1982) further advocated that the ethic of care represents a "very strong sense of being responsible to the world" (p. 21). Similarly, Tronto and Fisher (1990) posited, "Caring [can] be viewed as a species activity that includes everything... we do to maintain, continue, and repair our 'world' so that we can live in it as well as possible" (p. 40). Since the ethic of care represents a process for moral reasoning, it is reasonable to conclude this would emanate from various leadership styles.

\subsection{The Ethic of Care and its Impact on Various Leadership Styles}

In the wake of numerous scandals involving leadership in the corporate world including Enron's and Worldcom's abuses of managerial power, Machold et al. (2008) offered an alternative approach concerning a new corporate governance model integrating the ethic of care. They espoused that in opposition to an emphasis on power, rights, and obligations, the focus should be on relationships and care, encouraging leaders to have a sense of responsibility not only to their external stakeholders, but also to their followers. In fact, research (Atwijuka \& Caldwell, 2017; Collins, 2001; Gabriel, 2015; Rynes, Bartunek, Dutton, \& Margolis, 2012; Simola, Barling, \& Turner, 2010) has even hinted that leaders who tend to demonstrate the ethic of care are those who exemplify transformational, authentic, or servant leadership, each of which may have an influence on reducing teacher absenteeism, while increasing teacher retention.

\subsubsection{Transformational Leadership}

Transformational leaders serve as role models for their followers, establish a shared vision within the workplace, inspire innovation and creativity, and nurture a supportive environment (Bass, 1985; Bass \& Riggio, 2006), all characteristics implied in the ethic of care. Additionally, people who exhibit this style of leadership are characterized as "connected...[wherein] one's moral obligations... are grounded in a broader conception of individuals within the community" (Bass \& Steidlmeier, 1999, p. 186).

In a study on transformational and passive avoidance leadership, Frooman et al. (2012) revealed several findings of interest in mitigating the increased costs caused by employee absenteeism. Based on the questionnaire responses from 120 employees working for a national delivery service, the data revealed that transformational leadership had a negative effect on absenteeism $(\beta=-0.19, \mathrm{p}<0.05)$, while job satisfaction served as a mediating variable between the transformational leadership style and employee absenteeism.

With respect to retaining employees who are highly skilled, Dimaculangan and Aguiling (2012) studied 387 salespeople from six companies representing the pharmaceutical, real estate, and food and beverage industries. They found that transformational leadership negatively related to turnover intentions of employees to leave their companies $(\beta=-0.205, p<0.01)$. Therefore, they determined that companies who invested in a style of leadership that created an ethical climate and a sense of organizational commitment would more easily retain employees, dramatically cutting the overhead in hiring and training replacements for those who left the company, while saving the relationships created within their customer base.

\subsubsection{Authentic Leadership}

Authentic leadership has been gaining momentum across many disciplines including business, education, and government. In fact, there has been a call for authentic leaders who could help their employees find meaning and connection in their work, foster resilience in times of hardship, and build enduring organizations (Avolio \& Gardner, 2005). Moreover, research (Atwijuka \& Caldwell, 2017; Collins, 2001; Ilies, Morgeson, \& Nahrgang, 2005; Walumbwa, Avolio, Gardner, Wernsing, \& Peterson, 2008) has revealed the level of impact the ethic of care has on authentic leaders.

Drawing on the work of Kernis (2003) and Ilies et al. (2005), Walumbwa et al. (2008) focused on four basic components affiliated with authenticity including awareness (high levels of emotional intelligence), relational 
transparency (presenting the true self to others), balanced processing (collaborative decision making while avoiding personal biases), and moral perspective (maintaining an ethical approach to decision making). Atwijuka and Caldwell (2017) later confirmed the duality of the ethic of care, while noting how leaders are concerned about both organizational outcomes and meeting individual employees' needs. While various leaders who qualify as authentic leaders have produced a culture of genuineness and inspiration, research (Gatling, Kang, \& Kim, 2016; Oh \& Oh, 2017; Shapira-Lishchinsky \& Tsemach, 2014) has also supported that this leadership style has had an impact on employee absenteeism and employee retention.

In a study of 66 teachers from 23 Israeli schools regarding authentic leadership, Shapira-Lishchinsky and Tsemach (2014) explored how the mediating role of psychological empowerment, "a process of enhancing feelings of selfefficacy among organizational members" (p. 678), impacted employee withdrawal behaviors most evident in increased absenteeism, tardiness, and implicitly or explicitly expressed intentions to leave. As might be expected, the study revealed that authentic leadership had a positive effect on increasing psychological empowerment $(\beta=.431, p<.001)$ and psychological empowerment had a negative effect on teacher absenteeism $(\beta=-.214, \mathrm{p}<.01)$. Similarly, involving 236 students employed in the hospitality industry, Gatling et al. (2016) conducted a study exploring the effects of authentic leadership and organizational commitment on employee turnover intention. The data revealed that authentic leadership had a direct effect on employee turnover intentions $(\beta=-.11, \mathrm{p}<.05)$ and authentic leadership had a negative indirect effect on turnover intentions through organizational commitment $(\beta=-.09, \mathrm{p}<.05)$. Later, Oh and Oh (2017) further explored the effects of authentic leadership on employee turnover via affective commitment or an emotional attachment to an organization resulting in employees finding pleasure in being a part of their work community. After reviewing the survey data of 375 employees working in various South Korean businesses, they found that authentic leadership had a negative indirect effect on employee turnover intentions $(\beta=-0.13, \mathrm{p}<0.01)$.

Both transformational and authentic leaders tend to be kinder to employees, while intentionally motivating them to participate in undertakings that promote the goals of the organization. Taking transformational and authentic leadership styles one step further, servant leaders specifically focus on the well-being of the employee directly associating that leadership style to the ethic of care. Although servant leadership has not received the level of quantitative research as other leadership styles, the attributes found in the servant leader have drawn interest and practice by several leading businesses.

\subsubsection{Servant Leadership}

During the fifth century B.C., Chinese philosopher Lao-Tsu (trans. 1891) supported the fundamental truth regarding a servant leader by positing that "the sage does not accumulate [for himself]. The more that he expends for others, the more does he possess of his own; the more that he gives to others, the more does he have himself" (p. 123). Several centuries later, Jesus Christ explained to his disciples the meaning of servitude when he said, "But he who is the greatest among you shall be your servant" (Matthew 23:11, King James Version). This concept found its way into the more recent leadership literature in 1977 through the work of Robert Greenleaf who coined the term servant leader. Catapulting its distinction, he claimed that servant leadership "manifests itself in the care taken by the servant-first to make sure that other people's highest priority needs are being served" (p. 27), the foundation of the ethic of care.

In their review of servant leadership attributes, Russell and Stone (2002) postulated, "self-interest should not motivate servant leadership; rather, it should ascend to a higher plane of motivation that focuses on the needs of others" (p. 145). Later in his study concerning the main characteristics of this leadership perspective, Spears (2004) noted that many organizations have moved towards servant leadership because of the focus on the employees' and the customers' needs, both components of a caring leader.

While no specific studies concerning absenteeism and servant leadership were found, others (Jaramillo, Grisaffe, Chonko, \& Roberts, 2009; Sokoll, 2014) have indicated that it does increase employee retention. For example, in examining the employee turnover intention of 501 salespeople from various industries, Jaramillo et al. (2009) hypothesized that perceived ethical behavior (i.e., a cornerstone of servant leadership), person-organizational fit (i.e., congruent moral beliefs between the organization and the employee) and organizational commitment (i.e., the degree to which a salesperson identifies with the organization and the belief he or she is regarded as a valuable contributor) served as a "complex mediated and moderated chain-of-effects" (p. 352). While perceived ethical behavior had a positive effect on person-organizational fit $(\beta=0.26, \mathrm{p}<0.01)$ and organizational commitment $(\beta=0.05, \mathrm{p}<0.01)$, organizational commitment had a negative effect on turnover intention $(\beta=-0.54, p<0.01)$. Later, Sokoll (2014) surveyed 149 employees from a southwestern U.S. university and found that servant leadership had a significant positive effect on employee commitment to a supervisor $(\beta=0.65, \mathrm{p}<0.001)$, one of the antecedents to job satisfaction and thus employee retention. 


\section{Methodology}

Two research questions emerged from a review of the literature:

RQ1: Do principal leadership styles (transformational, authentic, and servant leadership) and the perceived ethic of care significantly predict teacher absenteeism in school divisions located in an urban setting?

RQ2: Do principal leadership styles (transformational, authentic, and servant leadership) and the perceived ethic of care significantly predict teacher retention in school divisions located in an urban setting?

\subsection{Population and Sample}

Two urban school divisions located in the southeastern United States, encapsulating 3,000 full-time teachers from 10 high schools, 13 middle schools, 43 elementary schools, two Pre-K-8 schools, one Grade 3-8 gifted center, and one Grade 9-12 Career Academy for Aviation served as the setting for this study.

\subsection{Instrumentation}

Teachers were asked to complete the 59 item Caring School Leadership Questionnaire (CSLQ), an instrument developed by Vyver, Westhuizen, and Meyer (2014b). Employing a 4-point Likert scale ranging from not at all to to a large extent, the CSLQ measures three determinants of care (psychological, organizational/workplace, and management) that serve as the foundation of the leadership styles explored in this study. The psychological (i.e., perceived emotional intelligence and level of empathy), organizational/workplace (i.e., care of the school facility), and management (i.e., leader's accessibility and collaborative leadership) determinants of care were each tallied separately and normed using their quartile scores resulting in four categories: low care, average care, above average care, and high care. In addition, teachers self-reported three critical factors: (a) the number of discretionary, sick, or personal development days they were absent from the start of the school year until late spring; (b) whether they intended to return to the same school building the following school year; and (c) their current teaching assignment: preschool, elementary, middle, or high school.

\section{Results}

This study had a $10.3 \%(n=309)$ response rate; however, 16 of the 37 teachers were excluded from the study after reporting they were not returning to their current assignment due either to retirement or some type of external circumstance such as a military spouse transfer or the need to relocate to lessen the commute time or to seek better earning potential. Of the remaining 293 teachers, 3.1\% $(n=9)$ taught preschool, 31.4\% $(n=92)$ taught elementary, $23.5 \%(n=69)$ taught middle, and $42 \%(n=123)$ taught high school.

\subsection{CSLQ Norms and Overall Descriptive Results}

Updated norms were calculated using the quartile scores for interpreting each determinant of care's (i.e., psychological, organizational/workplace, and management) range (i.e., low care, average care, above average care, and high care; see Table 1).

Table 1 CSLQ Norms Based on Responses to this Study

\begin{tabular}{llll}
\hline \multicolumn{2}{l}{ Raw score totals: Determinants of care } & & \\
\hline Psychological & Workplace & Management & Description \\
\hline$<59$ & $<27$ & $<61$ & Low care \\
$60-77$ & $28-32$ & $62-78$ & Average care \\
$78-93$ & $33-36$ & $79-91$ & Above average care \\
$>94$ & $>37$ & $>92$ & High care \\
\hline
\end{tabular}

In addition, Cronbach alphas for each determinant revealed the following: psychological (.98), organizational/workplace (.94), and management (.98), indicating high internal consistency based on scoring $\geq .70$ (Rovai, Baker, \& Ponton, 2013). Upon reviewing the descriptive statistics for the responses to the absenteeism scale, similarities among each level of care were noted as teachers indicated being absent from 1 to 4 days (see Table 2).

Table 2 Descriptive Statistics for Level of Care by Determinant and Teacher Absenteeism Responses

\begin{tabular}{llllllllll}
\hline & \multicolumn{3}{l}{ Psychological determinant } & \multicolumn{3}{l}{ Workplace determinant } & \multicolumn{3}{c}{ Management determinant } \\
\cline { 2 - 10 } Level of care & $M$ & $S D$ & $n$ & $M$ & $S D$ & $n$ & $M$ & $S D$ & $n$ \\
\hline Low care & 2.47 & 1.07 & 75 & 2.41 & 1.19 & 86 & 2.47 & 1.23 & 75 \\
Average care & 2.47 & 1.50 & 66 & 2.61 & 1.22 & 59 & 2.48 & 1.17 & 71 \\
Above average care & 2.54 & .89 & 72 & 2.47 & 1.04 & 59 & 2.78 & 1.17 & 63 \\
High care & 2.64 & 1.27 & 80 & 2.64 & 1.27 & 89 & 2.45 & 1.19 & 84 \\
\hline
\end{tabular}

Note. Teacher absenteeism ranges are $1=0$ days, $2=1-2$ days, $3=3-4$ days, $4=5-7$ days, $5=8-10$ days, and $6=11$ or more days. 
Regarding retention, 75\% $(n=220)$ of the respondents indicated they would return the following school year, while $7.2 \%(n=21)$ indicated they would not, and $17.7 \%(n=52)$ were still unsure.

\subsection{Teacher Absenteeism}

While conducting a multiple regression to determine if principal leadership style and the perceived ethic of care significantly predicted teacher absenteeism, the assumption of linearity in the residuals was violated as indicated by the Kolmogorov-Smirnov test, $\mathrm{D}(293)=.21, p<.0005$. In addition, box plots demonstrated there were no extreme outliers, however, the scatterplots yielded no evidence of any correlations among the determinants of care and teacher absenteeism. There was independence of the residuals, as assessed by a Durbin-Watson statistic of 1.80. Furthermore, there was high evidence of multicollinearity upon examination of the variance inflation factors (VIF) of the psychological (7.438) and management (10.352) determinants (see Table 3).

Table 3 Coefficients and Collinearity Statistics

\begin{tabular}{llllllll}
\hline & \multicolumn{2}{l}{$\begin{array}{l}\text { Unstandardized } \\
\text { coefficients }\end{array}$} & \multicolumn{2}{l}{$\begin{array}{l}\text { Standardized } \\
\text { coefficients }\end{array}$} & \multicolumn{3}{c}{ Collinearity statistics } \\
\hline 1 Model & \multicolumn{1}{ll}{ B } & \multicolumn{1}{l}{$S E$} & Beta & \multicolumn{1}{c}{ S } & Sig. & Tolerance & \multicolumn{1}{l}{ VIF } \\
\hline (Constant) & 2.353 & .316 & & 7.454 & .000 & & \\
Psychological & .007 & .009 & .120 & .746 & .456 & .134 & 7.438 \\
Workplace & .010 & .018 & .058 & .532 & .595 & .293 & 3.411 \\
Management & -.009 & .012 & -.134 & -.707 & .480 & .097 & 10.352 \\
\hline
\end{tabular}

Note. . Dependent variable $=$ teacher absenteeism.

The results from the multiple regression provided no evidence that principal leadership style and perceived ethic of care predicted teacher absenteeism, $F(3,289)=.33, p=.80$. In addition, statistical significance was untenable again after computing the summation for all the teacher responses creating a new variable, perceived care.

\subsection{Teacher Retention}

Initially, a multinomial logistic regression was employed to determine if principal leadership style and the perceived ethic of care significantly predicted teacher retention, however, SPSS Windows version 25 noted there were 543 cells with zero frequencies and unexpected singularities in the Hessian matrix. While running this statistic and receiving this alert, Ray (2015) suggested reducing the number of categories and the number of cells in the analysis by collapsing the categories in the dependent variables. Therefore, the dependent variables no and unsure were combined resulting in a dichotomous variable set of yes and no/unsure changing the statistic employed from a multinomial to a binomial logistic regression. In contrast to teacher absenteeism and in examining teacher retention, the binomial logistic regression model was statistically significant, $\mathrm{X}^{2}(3)=23.231, \mathrm{p}<.0005$. The model explained $11.3 \%$ (Nagelkerke $\mathrm{R}^{2}$ ) of the variance in teacher retention and correctly classified $75.8 \%(\mathrm{n}=222)$ of cases, although the baseline model excluding the three determinants of care would have correctly classified teacher retention in $75.1 \%(\mathrm{n}=220)$ of the cases. Sensitivity was $96.8 \%(\mathrm{n}=213)$, specificity was $12.3 \%(\mathrm{n}=9)$, positive predictive value was $76.9 \%$, and negative predictive value was $56.3 \%$ (see Table 4 ).

Table 4 Classification Table ${ }^{\mathrm{a}}$

\begin{tabular}{lclll}
\hline & \multicolumn{4}{l}{ Predicted } \\
& \multicolumn{2}{l}{ returnY_N/Unsure } \\
Observed & .00 & 1.00 & Percentage correct \\
\hline Step 1 returnY_N/Unsure & .00 & 9 & 64 & 12.3 \\
\hline & 1.00 & 7 & 213 & 96.8 \\
\hline Overall percentage & & & & 75.8 \\
\hline
\end{tabular}

a. The cut value is .500 .

Oddly, none of the three predictor variables demonstrated statistical significance (see Table 5).

Table 5 Variables in the Equation

\begin{tabular}{crlrllr}
\hline & \multicolumn{1}{c}{ B } & \multicolumn{1}{c}{$S E$} & Wald & $d f$ & Sig. & Exp(B) \\
\hline Step $1^{\mathrm{a}}$ Psychological & .009 & .018 & .240 & 1 & .624 & 1.009 \\
Workplace & -.035 & .036 & .980 & 1 & .322 & .965 \\
Management & .036 & .024 & 2.341 & 1 & .126 & 1.037 \\
Constant & -1.019 & .588 & 2.997 & 1 & .083 & .361 \\
\hline
\end{tabular}

a. Variable(s) entered on step 1: Psychological, Workplace, Management. 
In contrast, statistical significance was found tenable, $\mathrm{X}^{2}(1)=21.237, p<.0005$, with the model and the predictor variable, total_scale, a transformed variable after the summation of the three determinants of care. However, the assumption of no extreme multicollinearitywas not met as was the case found in RQ1. The model explained $10.4 \%$ $\left(\right.$ Nagelkerke $\mathrm{R}^{2}$ ) of the variance in teacher retention and correctly classified $76.8 \%(\mathrm{n}=226)$ of cases. Sensitivity was $97.7 \%(\mathrm{n}=215)$, specificity was $13.7 \%(\mathrm{n}=10)$, positive predictive value was $77.3 \%$ and negative predictive value was $66.7 \%$ (see Table 6 ).

Table 6 Classification Table ${ }^{a}$

\begin{tabular}{lrrrr}
\hline & \multicolumn{3}{l}{ Predicted } \\
& \multicolumn{3}{c}{ returnY_N/Unsure } \\
Observed & & .00 & 1.00 & Percentage correct \\
\hline Step 1 returnY_N/Unsure & .00 & 10 & 63 & 13.7 \\
\hline & 1.00 & 5 & 215 & 97.7 \\
\hline Overall percentage & & & & 76.8 \\
\hline
\end{tabular}

a. The cut value is .500 .

The variable total_scale revealed that teachers were 1.014 times more likely to respond yes and return to their current teaching assignment the next school year as opposed to responding no/unsure (see Table 7).

Table 7 Variables in the Equation

\begin{tabular}{crlrllc}
\hline & \multicolumn{1}{l}{ B } & SE & \multicolumn{1}{c}{ Wald } & $d f$ & Sig. & Exp(B) \\
\hline Step 1 ${ }^{\text {a }}$ total_scale & .014 & .003 & 20.214 & 1 & .000 & 1.014 \\
\hline Constant & -1.286 & .533 & 5.822 & 1 & .016 & .276
\end{tabular}

a. Variable(s) entered on step 1: total_scale.

\section{Discussion}

Although this study lacked generalizability due to its lower than anticipated response rate, it did contribute to the research concerning a principal's leadership style and his or her perceived ethic of care with respect to teacher absenteeism and retention, while also recommending areas for future research.

\subsection{Teacher Absenteeism}

The hypothesis that leadership style is grounded in the ethic of care and could reliably predict teacher absenteeism was not realized as the multiple regression provided no statistical significance, $F(3,289)=.33, p=.80$. Moreover, the transformed variable, perceived caring derived by calculating the sum of all three determinants of care, yielded no statistically significant findings.

While the foundation of transformational, authentic, and servant leadership--to convey adherence to ethical responsibility, increase self-efficacy within the organization's members, and encourage a greater sense of community-has been demonstrated in the literature (Frooman et al., 2012; Jaramillo et al., 2009; Shapira-Lishchinsky \& Tsemach, 2014), the findings in this study were unexpected. In fact, previous studies (Pitts, 2010; Steers \& Rhodes, 1978) have illustrated the process of teacher absenteeism leading to teacher turnover, which guided the initial hypothesis for this study that principal leadership styles and perceived ethic of care would predict teacher absenteeism.

There were numerous issues that may have affected the findings regarding this RQ. First, while all teachers in the two urban school divisions were invited to participate in this study, only $10.3 \%$ chose to respond falling well below Creswell's (2012) recommended 50\% to 75\%. Nonetheless, experiencing a lower response rate has become commonplace when conducting survey research studies in the field of education due to numerous participant invitations. In addition, this study was approved by one school division at the beginning of their End-of-Course testing window potentially contributing to the lower response rate as teachers were much more limited in their available time.

Second, during this study, two duplicate emails were sent to teachers to encourage participation. In their online survey research of 24,000 junior scientists, Sauermann and Roach (2013) found three things that dramatically improved response rates: (a) using participants' first names in all correspondence, (b) offering incentives, and (c) modifying the verbiage in follow-up emails. Implementing these recommendations is suggested for future studies.

Third, since most of the teachers self-reported absences from 1 to 4 days during the academic year, an issue may have existed pertaining to the scale within the questionnaire; it may have needed smaller incremental delineation.

Another explanation might be that teachers simply did not recall the exact number of days they had missed and this category was the most appealing. 
Finally, the assumption for the absence of extreme multicollinearity was violated as evidenced by the VIFs for the psychological and management determinants, while implying they cross-loaded. Interestingly, the possibility of crossloading was further evident for these two determinants based on the variations between the norms configured in this study as compared to the original conducted by Vyver et al. (2014b). In fact, there was a 20-point raw score variation among the ranges for low and average care and a 10-point variation in the range regarding above average care; however, the ranges with respect to the norms for the organizational/workplace determinant were similar in the two studies.

\subsection{Teacher Retention}

With respect to the impact of school leadership on teachers, this research supported and furthered previous studies of Cherian and Daniel (2008), Lynch, (2012), Louis, Murphy, and Smylie (2016), Sammons et al. (2011), and others (Gatling et al., 2016; Jaramillo et al., 2009; Kara, Uysal, Sirgy, \& Lee, 2013) that more specifically addressed leadership styles and the perceived ethic of care in predicting employee turnover. As teachers are increasingly choosing to leave the profession within the first five years of employment, especially in urban environments, Manullang (2017) posited the importance of school principals to improve on their soft skills such as building better teacher relationships as characterized by the underpinnings in the three leadership styles found in this study.

Likewise, it is essential when principals view leadership through the lens of the ethic of care, they do so with a servant leader's heart as opposed to one of power (Sergiovanni, 1992; Vyver, Westhuizen, \& Meyer, 2014a). In so doing, the acquisition of additional school leaders is not the priority as Sergiovanni (1992) mentioned, but rather hiring better leaders who are able to call upon the virtue of moral responsibility through care. Since a calling to be morally responsible forms the basis of transformational, authentic, and servant leadership styles, principals can exhibit their commitment to care by ensuring teachers have access to resources needed to carry out instruction and work in wellmaintained buildings. While the questions on the CSLQ are centered on the teacher's perception of their principal's commitment to care, it was clear in this study that teachers planning to return the following school year do so based upon the softer leadership characteristics exhibited by their leaders.

Surprisingly, neither the psychological, organizational/workplace, nor management determinants of care demonstrated statistical significance individually when predicting teacher retention as revealed in the Variables in the Equation in SPSS. However, the cumulative total of the item responses in the CSLQ did reveal statistical significance.

\subsection{Recommendations for Future Research}

First, issues with multicollinearity were experienced in this study related to two of the three determinants of care: psychological and management. As stated by Rovai et al. (2013), an acceptable method for determining "if the measures created to represent a latent variable really belong together" (p. 440) is by performing a confirmatory factor analysis.

Second, despite previous research (Miller, 2012; Miller et al., 2008) demonstrating how problematic teacher absenteeism has become, particularly in urban schools, this study yielded surprising results finding no significant relationship between school principals exhibiting the styles of leadership associated with the ethic of care and whether or not teachers came to work. This causes one to question if there may have been a problem with the scale that was used to evaluate this variable or if one should avoid self-reported measures altogether (Loevinger, 1957). For the most accurate report of teacher absences, future research should consider directly using a school division's attendance dataset; however in doing so, issues with anonymity would then need to be addressed.

Third, demographic data collection was limited to inquiring about a teacher's current level of assignment. It is recommended that any future study include additional demographics such as teacher age, sex, ethnicity, and level of education to determine if there are any other relationships or tendencies concerning the impact a school principal has on both teacher absenteeism and retention rates.

\section{Conclusion}

The results from this study vigorously point to the need for transformational, authentic, and servant leaderships styles coupled with the ethic of care to be embedded within school leadership preparation programs. In addition, school divisions should consider providing opportunities for personal and professional growth regarding the underpinnings found in these leadership styles based on the ethic of care, thus encouraging not only instructional, but also moral leadership. 


\section{References}

Atwijuka, S., \& Caldwell, C. (2017). Authentic leadership and the ethic of care. The Journal of Management Development, 36(8), 1040.

Avolio, B. J., \& Gardner, W. L. (2005). Authentic leadership development: Getting to the root of positive forms of leadership. The Leadership Quarterly, 16(3), 315-338.

Bass, B. M. (1985). Leadership and performance beyond expectations. New York, NY: Free Press.

Bass, B. M., \& Riggio, R. E. (2006). Transformational leadership (2nd ed.). Mahwah, NJ: Lawrence Erlbaum.

Bass, B. M., \& Steidlmeier, P. (1999). Ethics, character, and authentic transformational leadership behavior. Leadership Quarterly, 10, 181-217.

Cherian, F., \& Daniel, Y. (2008). Principal leadership in new teacher induction: Becoming agents of change. International Journal of Education Policy and Leadership, 3(2), 1-11.

Clotfelter, C. T., Ladd, H. F., \& Vigdor, J. L. (2009). Are teacher absences worth worrying about in the United States? Education Finance and Policy, 4(2), 115-149.

Collins, J. C. (2001). Good to great: Why some companies make the leap . . . and others don't. New York, NY: HarperBusiness.

Creswell, J. W. (2012). Educational research: Planning, conducting, and evaluating quantitative and qualitative research (4th ed.). Upper Saddle River, NJ: Pearson.

Dimaculangan, E. D., \& Aguiling, H. M. (2012). The effects of transformational leadership on salesperson's turnover intention. International Journal of Business and Social Science, 3(19), 197-210.

Frooman, J., Mendelson, M. B., \& Murphy, K. J. (2012). Transformational and passive avoidant leadership as determinants of absenteeism. Leadership \& Organization Development Journal, 33(5), 447-463.

Gabriel, Y. (2015). The caring leader - What followers expect of their leaders and why? Leadership, 11(3), 316-334.

Gallant, A., \& Riley, P. (2014). Early career teacher attrition: New thoughts on an intractable problem. Teacher Development, 18(4), 562-580.

Gatling, A., Kang, H. J. A., \& Kim, J. S. (2016). The effects of authentic leadership and organizational commitment on turnover intention. Leadership \& Organization Development Journal, 37(2), 181-199.

Gilligan, C. (1982). In a different voice: Psychological theory and women's development. Cambridge, MA: Harvard University Press.

Greenleaf, R. K. (1977). Servant leadership. New York, NY: Paulist Press.

Ilies, R., Morgeson, F. P., \& Nahrgang, J. D. (2005). Authentic leadership and eudaemonic well-being: Understanding leader-follower outcomes. The Leadership Quarterly, 16(3), 373-394.

Ingersoll, R., Merrill, L., \& Stuckey, D. (2014). Seven trends: The transformation of the teaching force. Retrieved from http://www.cpre.org/7trends

Jaramillo, F., Grisaffe, D. B., Chonko, L. B., \& Roberts, J. A. (2009). Examining the impact of servant leadership on salesperson's turnover intention. The Journal of Personal Selling and Sales Management, 29(4), 351-365.

Kara, D., Uysal, M., Sirgy, M. J., \& Lee, G. (2013). The effectsof leadership style on employee well-being in hospitality. International Journal of Hospitality Management, 34, 9-18.

Kernis, M. H. (2003). Toward a conceptualization of optimal self-esteem. Psychological Inquiry, 14(1), 1-26.

Kohlberg, L. (1968). The Child as a Moral Philosopher. Psychology Today, 2(4), 24-30.

Lao-Tsu. (1891). Tao teching. (J. Legge \& M. F. Muller, Trans.) The sacred books of the east Vol. 39. Retrieved from https://archive.org/details/in.ernet.dli.2015.45262

Loevinger, J. (1957). Objective tests as instruments of psychological theory. Psychological Reports, 3(3), 635-694.

Louis, K. S., Murphy, J., \& Smylie, M. (2016). Caring leadership in schools: Findings from exploratory analyses. Educational Administration Quarterly, 52(2), 310.

Lynch, M. (2012). Recruiting, retaining, and fairly compensating our teachers. International Journal of Progressive Education, 8(2), 121-135.

Machold, S., Ahmed, P. K., \& Farquhar, S. S. (2008). Corporate governance and ethics: A feminist perspective. Journal of Business Ethics, 81(3), 665-678.

Manullang, M. (2017). The effect of soft skills, competence and human relations skills on principal leadership. International Journal of Academic Research in Economics and Management Sciences, 6(4),14-27.

Miller, R. (2012). Teacher absence as a leading indicator of student achievement. Retrieved from https://www.americanprogress.org/issues/education/reports/ 2012/11/05/40371/teacher-absence-as-a-leadingindicator-of-student-achievement

Miller, R. T., Murnane, R. J., \& Willett, J. B. (2008). Do worker absences affect productivity? The case of teachers. International Labour Review, 147(1), 71-89. 
National Council on Teacher Quality. (2014, June).Roll call: The importance of teacher attendance. Retrieved from https://www.nctq.org/dmsView/RollCall_Teacher Attendance

Noddings, N. (1984). Caring: A feminine approach to ethics and moral education. Los Angeles, CA: University of California Press.

Oh, J., \& Oh, S. (2017). Authentic leadership and turnover intention: Does organizational size matter? Leadership \& Organization Development Journal, 38(7), 912-926.

Pitts, K. L. (2010). Teacher absenteeism: An examination of patterns and predictors (Doctoral dissertation). Retrieved from http://udini.proquest.com/view/teacher-absenteeism-an-examination-goid:305250728/

Ray, S. (2015, November 26). Simple methods to deal with categorical variables in predictive modeling. Retrieved from https://www.analyticsvidhya.com/blog/2015/11/easy-methods-deal-categorical-variables-predictivemodeling/

Rovai, A. P., Baker, J. D., \& Ponton, M. K. (2013). Social science research design and statistics: A practitioner's guide to research methods and IBM SPSS analysis (2nd ed.). Chesapeake, VA: Watertree Press.

Russell, R. F., \& Stone, G. A. (2002). A review of servant leadership attributes: Developing a practical model. Leadership \& Organization Development Journal, 23(3), 145-157.

Rynes, S. L., Bartunek, J. M., Dutton, J. E., \& Margolis, J. D. (2012). Care and compassion through an organizational lens: Opening up new possibilities. Academy of Management. The Academy of Management Review, 37(4), 503.

Sammons, P., Gu, Q., Day, C., \&Ko, J. (2011). Exploring the impact of school leadership on pupil outcomes. International Journal of Educational Management, 25(1), 83-101.

Sauermann, H., \& Roach, M. (2013). Increasing web survey response rates in innovation research: An experimental study of static and dynamic contact design features. Research Policy, 42(1), 273-286.

Sergiovanni, T. J. (1992). Moral leadership: Getting to the heart of school improvement. San Francisco, CA: JosseyBass.

Shapira-Lishchinsky, O., \&Tsemach, S. (2014). Psychological empowerment as a mediator between teachers' perceptions of authentic leadership and their withdrawal and citizenship behaviors. Educational Administration Quarterly, 50(4), 675-712

Simola, S. K., Barling, J., \& Turner, N. (2010). Transformational leadership and leader moral orientation: Contrasting an ethic of justice and an ethic of care. The Leadership Quarterly, 21(1), 179-188.

Sokoll, S. M. (2014). Servant leadership and employee commitment to a supervisor. International Journal of Leadership Studies, 8(2), 88-104.

Spears, L. C. (2004). Practicing servant-leadership. Leader to Leader, 2004(34), 7-11.

Steers, R. M., \& Rhodes, S. R. (1978). Major influences on employee attendance: A process model. Journal of Applied Psychology, 63(4), 391-407.

Tronto, J.C., \& Fisher, B. (1990). Towards a feminist theory of caring. In Abel, E. K., \& Nelson, M. K. (1990). Circles of care: Work and identity in women's lives. Albany, NY: State University of New York Press.

Vyver, C. P., Westhuizen, P. C., \& Meyer, L. W. (2014a). Caring school leadership: A South African study. Educational Management Administration \& Leadership, 42(1), 61-74.

Vyver, C. P., Westhuizen, P. C., \& Meyer, L. W. (2014b). The caring school leadership questionnaire (CSLQ). South African Journal of Education, 34(3), 1-7.

Walumbwa, F. O., Avolio, B. J., Gardner, W. L., Wernsing, T. S., \& Peterson, S. J. (2008). Authentic leadership: Development and validation of a theory-based measure. Journal of Management,34(1), 89-126. 